\title{
Relationship between the Surface Roughness of Biodegradable Mg-Based Bulk Metallic Glass and the Osteogenetic Ability of MG63 Osteoblast-Like Cells
}

\author{
Pei-Chun Wong ${ }^{1,+}\left(\mathbb{D}\right.$, Sin-Mao Song ${ }^{2,+}{ }^{+}$Pei-Hua Tsai ${ }^{2}$, Yi-Yuan Nien ${ }^{2}$, \\ Jason Shian-Ching Jang 2,3,*, Cheng-Kung Cheng ${ }^{4, *} \mathbb{D}$ and Chih-Hwa Chen 1,5,6,7,* \\ 1 School of Biomedical Engineering, College of Biomedical Engineering, Taipei Medical University, Taipei 110, \\ Taiwan; s0925135546@gmail.com \\ 2 Institute of Materials Science and Engineering, National Central University, Taoyuan 320, Taiwan; \\ bear82112760103@gmail.com (S.-M.S.); peggyphtsai@gmail.com (P.-H.T.); gyes975212@gmail.com (Y.-Y.N.) \\ 3 Department of Mechanical Engineering, National Central University, Taoyuan 320, Taiwan \\ 4 School of Biomedical Engineering, Shanghai Jiao Tong University, Shanghai 200240, China \\ 5 Department of Orthopedics, Taipei Medical University - Shuang Ho Hospital, New Taipei 235, Taiwan \\ 6 School of Medicine, College of Medicine, Taipei Medical University, Taipei 110, Taiwan \\ 7 Research Center of Biomedical Device, Taipei Medical University, Taipei 110, Taiwan \\ * Correspondence: jscjang@ncu.edu.tw (J.S.-C.J.); ckcheng2009@gmail.com (C.-K.C.); \\ afachen@doctor.com (C.-H.C.); Tel.: +886-3-4267-397 (J.S.-C.J.); +886-2-2736-1661 (C.-H.C.); \\ Fax: +886-3-425-4501 (J.S.-C.J.) \\ + Both authors contributed equally to this work.
}

Received: 30 January 2020; Accepted: 4 March 2020; Published: 6 March 2020

\begin{abstract}
Mg-based bulk metallic glass materials have been investigated for their large potential for application in orthopedic implants due to their biocompatibility, low degradation rate, and osteogenetic ability. As an orthopedic implant, initial cell adhesion has been a critical issue for subsequent osteogenesis and bone formation because the first contact between cells and the implant occurs upon the implants surface. Here, we aimed to create Mg-based bulk metallic glass samples with three different surface roughness attributes in order to understand the degradation behavior of Mg-based bulk metallic glass and the adhesion ability and osteogenetic ability of the contact cells. It was found that the degradation behavior of $\mathrm{Mg}_{66} \mathrm{Zn}_{29} \mathrm{Ca}_{5}$ bulk metallic glass was not affected by surface roughness. The surface of the $\mathrm{Mg}_{66} \mathrm{Zn}_{29} \mathrm{Ca}_{5}$ bulk metallic glass samples polished via \#800 grade sandpaper was found to offer a well-attached surface and to provide a good cell viability environment for Human MG63 osteoblast-like cell line. In parallel, more calcium and mineral deposition was investigated on extracellular matrix with higher surface roughness that verify the relationship between surface roughness and cell performance.
\end{abstract}

Keywords: Mg-based bulk metallic glass; biodegradable; surface roughness; osteogenetic

\section{Introduction}

Mg-based materials have been investigated in recent years for their application in the medical field due to their attractive biocompatibility, biodegradability, and osteogenic abilities. For orthopedic implant applications, Mg-based materials have great potential for interference screws, suture anchors, or bioscrews for bone-bone fixation or bone-tendon/ligament fixation. The release of $\mathrm{Mg}^{2+}$ ions during Mg-based material degradation is a mechanism known to enhance osteoconductive, osteoinductive, and osteogenesis ability. 
As an orthopedic implant, the surface of the metallic implant is the initial interface that contacts with the bone tissue; thus, the surface roughness of the metallic material is an important consideration, especially when analyzing the interaction between the surface roughness of metallic materials and osteoblasts [1-3]. For this reason, the surface roughness of implants has been varied and modified by different surface treatments, such as function coating, in an effort to support the cells initial attachment $[4,5]$. The materials that are commonly used in orthopedic implants, such as Ti alloys and stainless steel, have been investigated for optimal surface roughness, which has been found to affect the adhesion and subsequent osteogenic function of osteoblasts [6-9]. The degree of surface roughness has been found to have a limitation window for optimal cell attachment; this window varies with the kinds of cells and materials. For example, the titanium with the surface roughness of 3 um was more suitable than $0.5 \mathrm{um}$ for human osteoblasts differentiation [10]. The titanium with $1.03 \mu \mathrm{m}$ of surface roughness can offer a better cell response for MC3T3-E1 mouse pre-osteoblast cell line in comparison with the smooth surface samples [11].

Mg-based implant materials are subject to degradation by bodily fluids, and the extent of degradation increases over time. For crystalline Mg-based materials, the spalling phenomenon was first demonstrated on the surface of materials. The following intergranular corrosion and intergranular stress corrosion cracking (IGSCC) have been found to lead to failure of the material [12]. The degradation of amorphous Mg-based materials occurs uniformly and homogeneously; however, the surface roughness varies according to the formation of the products of corrosion and degradation vestiges that occur during degradation process [13]. The surface of biodegradable Mg-based materials was not found to be stable surface because of the surface roughness variation, which is subject to the degradation process and changes all the time [14]. According to the theory, a rough surface would create a more exposed surface for degradation to occur and this surface would therefore increase the degradation rate [14]. The corrosion behavior of Mg alloy has previously been reported by Alvarez et al. [15] and Walter et al. [16]; these reports have focused on the changes to the surface topography, chemical composition distribution, and pitting corrosion after the immersion test. Unfortunately, there are few studies investigating the relationship between degradation behavior and surface roughness of Mg-based material, or the relationship between osteogenesis ability of cells and surface roughness of Mg-based materials.

In this study, we created $\mathrm{Mg}_{66} \mathrm{Zn}_{29} \mathrm{Ca}_{5}$ bulk metallic glass materials of three different surface roughness by polishing with sandpaper in order to compare degradation behavior, cell adhesion ability, cell viability, and osteogenesis ability (Figure 1). We hypothesized that the rougher surface roughness of $\mathrm{Mg}_{66} \mathrm{Zn}_{29} \mathrm{Ca}_{5}$ bulk metallic glass may provide a suitable surface for cell adhesion and improved osteogenetic ability. The results of these tests demonstrate the behavior of biodegradable Mg-based material over a range of different surface roughness that can be further applied to the design and manufacture process of biodegradable Mg-based orthopedic implants.

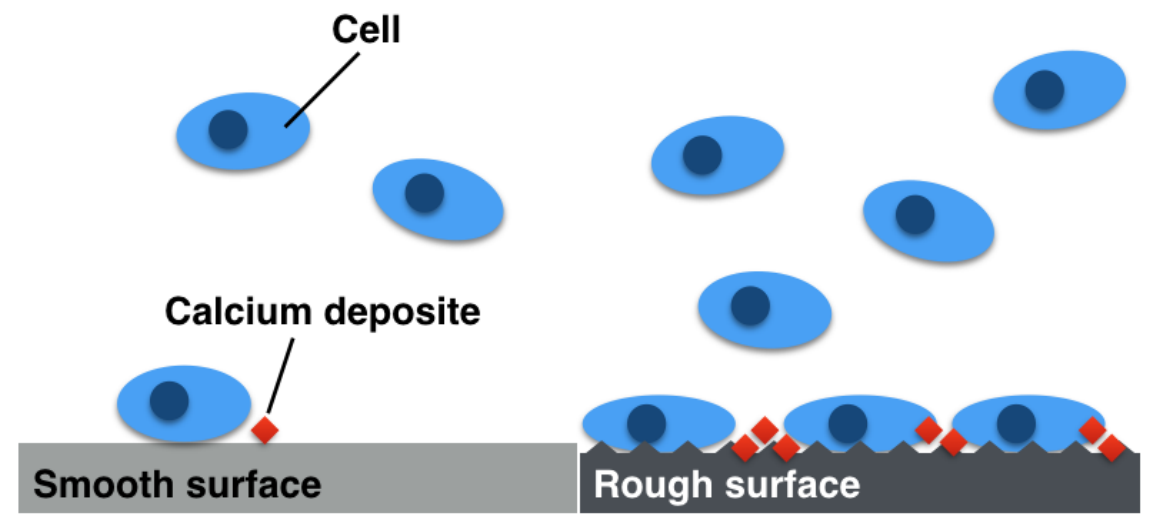

Figure 1. The relationship between $\mathrm{Mg}_{66} \mathrm{Zn}_{29} \mathrm{Ca}_{5}$ bulk metallic glass with varying surface roughness and MG63 cell adhesion, and the following calcium extracellular matrix deposition. 


\section{Materials and Methods}

\subsection{Study Design}

The objectives of this study were to analyze the optimal surface roughness for cell adhesion and further osteogenetic capability of MG63 osteoblast-like cells (Bioresource Collection and Research Center, Hsinchu, Taiwan) on $\mathrm{Mg}_{66} \mathrm{Zn}_{29} \mathrm{Ca}_{5}$ bulk metallic glass. Here, we focused on the adhesion cell morphology and the osteogenic sign of MG63 cells on $\mathrm{Mg}_{66} \mathrm{Zn}_{29} \mathrm{Ca}_{5}$ bulk metallic glass surface with the different surface roughness; fundamental material properties were also analyzed. In this study, three $\mathrm{Mg}_{66} \mathrm{Zn}_{29} \mathrm{Ca}_{5}$ bulk metallic glass samples of differing surface roughness were processed via surface treatment using sandpaper polishing (\#240,\#800, and \#2000).

\subsection{Sample Preparation and Composition Identification}

$\mathrm{Mg}_{66} \mathrm{Zn}_{29} \mathrm{Ca}_{5}$ bulk metallic glass was prepared by the induction melting and injection casting method under an argon atmosphere. Initially, $\mathrm{Mg}, \mathrm{Zn}$, and $\mathrm{Ca}$ were melted using the induction melting method to form the $\mathrm{Mg}_{66} \mathrm{Zn}_{29} \mathrm{Ca}_{5}$ ingot. The ingot of $\mathrm{Mg}_{66} \mathrm{Zn}_{29} \mathrm{Ca}_{5}$ was then re-melted in a quartz tube and injected into a water-cooled $\mathrm{Cu}$ mold under an argon atmosphere to form $\mathrm{Mg}_{66} \mathrm{Zn}_{29} \mathrm{Ca}_{5} \mathrm{BMG}$ plate, and then cut into dimensions of $10 \mathrm{~mm} \times 10 \mathrm{~mm} \times 1.5 \mathrm{~mm}$.

\subsection{Microstructure Analysis}

The amorphous state and phase composition of the $\mathrm{Mg}_{66} \mathrm{Zn}_{29} \mathrm{Ca}_{5} \mathrm{BMG}$ samples with different surface roughness were analyzed by X-ray diffraction (XRD) using a D8AXRD X-ray diffractometer (Bruker, Karlsruhe, Germany) with monochromatic $\mathrm{Cu}$ Ka radiation.

\subsection{Surface Roughness Analysis}

The $\mathrm{Mg}_{66} \mathrm{Zn}_{29} \mathrm{Ca}_{5}$ BMG samples with three different surface roughness attributes were analyzed using an Alpha-step profilometer (KLA-Tencor, Milpitas, CA, USA) to determine the relationship between the actual surface roughness and the different sandpaper grades used to polish to $\mathrm{Mg}_{66} \mathrm{Zn}_{29} \mathrm{Ca}_{5}$ BMG surface.

\subsection{Degradation Behavior Investigation}

The degradation behavior of the $\mathrm{Mg}_{66} \mathrm{Zn}_{29} \mathrm{Ca}_{5} \mathrm{BMG}$ plate samples with different surface roughness parameters was investigated using the immersion method with simulated body fluid (SBF; $8.0 \mathrm{~g} \mathrm{NaCl}$, $0.4 \mathrm{~g} \mathrm{KCl}, 0.14 \mathrm{~g} \mathrm{CaCl}_{2}, 0.35 \mathrm{~g} \mathrm{NaHCO}_{3}, 0.1 \mathrm{~g} \mathrm{MgCl}_{2} \cdot 6 \mathrm{H}_{2} \mathrm{O}, 0.06 \mathrm{~g} \mathrm{MgSO} \cdot 7 \mathrm{H}_{2} \mathrm{O}, 0.06 \mathrm{~g} \mathrm{KH}_{2} \mathrm{PO}_{4}$, and $0.06 \mathrm{~g} \mathrm{Na}_{2} \mathrm{HPO}_{4} \cdot 12 \mathrm{H}_{2} \mathrm{O}$ dissolved in $1 \mathrm{~L}$ deionized water $)(0.3 \mathrm{~mL} / \mathrm{mm} 2)$ at a temperature of $37^{\circ} \mathrm{C}$, according to the standard ASTM G31-72 [17]. After different immersion periods (0, 1, 2, 3, and 4 weeks), the SBF was removed and the samples were rinsed with deionized (DI) water. After the samples were dried, the weight of the samples and the $\mathrm{pH}$ value of the SBF were recorded using an electronic balance (Waga Aanalityczna AS 220.R2, Radwag Wagi Elektroniczne, Radom, Poland) and pH meter (PH500, Clean, New Taipei, Taiwan), respectively. The surface roughness of each of the samples was also measured and recorded.

\subsection{Cell Adhesion Observation and Spreading Calculation}

The cell adhesion and spreading behavior of the MG63 osteoblast-like cells were captured by scanning electron microscopy (SEM) (SU3500; Hitachi, Tokyo, Japan). The MG63 osteoblast-like cells were cultured in high-glucose Dulbecco's modified Eagle medium (DMEM; Gibco ${ }^{\circledR}$, Carlsbad, CA, USA) supplemented with $10 \%$ fetal bovine serum (Gibco ${ }^{\circledR}$, Carlsbad, CA, USA). The $\mathrm{Mg}_{66} \mathrm{Zn}_{29} \mathrm{Ca}_{5}$ BMG plates were placed in a 48-well culture plate, after which 3000 cells/well $(2727$ cells/cm²) MG63 osteoblast-like cells were seeded into the well and subjected to $24 \mathrm{~h}$ of incubation in an incubator set at $37{ }^{\circ} \mathrm{C}$ in an atmosphere of $5 \% \mathrm{CO}_{2}$. Prior to observations, fixation, and dehydration processes 
were used to prepare the samples for SEM. The cell spreading area present on the surface of the $\mathrm{Mg}_{66} \mathrm{Zn}_{29} \mathrm{Ca}_{5} \mathrm{BMG}$ plates was calculated and quantified using Image J software in order to determine the relationship between the different surface roughness attributes of the $\mathrm{Mg}_{66} \mathrm{Zn}_{29} \mathrm{Ca}_{5} \mathrm{BMG}$ samples and cell adhesion ability.

\subsection{Cell Viability Test (MTT Assay)}

Cell viability tests were performed on the samples via the direct contact method. The placement of the materials and the cell culture process was undertaken as per the cell adhesion test. After three days incubation, the $\mathrm{Mg}_{66} \mathrm{Zn}_{29} \mathrm{Ca}_{5}$ BMG plates were located to a new 48-well culture plate to ensure that the cells that were analyzed all adhered to the surface. Ten microliters of MTT (3-(4,5-dimethylthiazol-2-yl)2,5-diphenyltetrazolium bromide) solution (Invitrogen, Carlsbad, CA, USA) was then added carefully to each well, and incubation was done for a further $3 \mathrm{~h}$. One-hundred microliters of dimethylsulfoxide was then placed into each well, and the optical density value was detected using an enzyme-linked immune-sorbent assay reader at a wavelength of $560 \mathrm{~nm}$ (Multiskan FC; Thermo, Waltham, MA, USA).

\subsection{Extracellular-matrix Calcium Deposition Detection}

MG63 osteoblast-like cells were used to facilitate extracellular-matrix calcium deposition by the ions released from the $\mathrm{Mg}_{66} \mathrm{Zn}_{29} \mathrm{Ca}_{5} \mathrm{BMG}$ plates with different surface roughness. The $\mathrm{Mg}_{66} \mathrm{Zn}_{29} \mathrm{Ca}_{5}$ BMG plates with different surface roughness were treated with the cell culture process through the same method as for the cell adhesion test. After incubation for 7 days, the $\mathrm{Mg}_{66} \mathrm{Zn}_{29} \mathrm{Ca}_{5} \mathrm{BMG}$ plates were transferred to another 48-well culture plate. Cells were fixed using 4\% paraformaldehyde, and Alizarin Red S (ARS), a staining dye, was used to stain the calcium deposits generated by the MG63 cells. After $40 \mathrm{~min}$, the ARS dye was removed and solubilized with $100 \mu \mathrm{L}$ of DMSO for $30 \mathrm{~min}$, and the optical density was measured at $590 \mathrm{~nm}$ with an enzyme-linked immune-sorbent assay reader (Spectra Max 190, Molecular Device, San Jose, CA, USA).

\subsection{Migration Test}

For the migration test, in vitro scratch assay was used to investigate the migration ability of the MG63 osteoblast-like cells. The $\mathrm{Mg}_{66} \mathrm{Zn}_{29} \mathrm{Ca}_{5}$ BMG plates with different surface roughness were first placed in 48-well culture plate, after which 5000 cells from the cell suspension were suspended in a 48-well culture plate and incubated for $6 \mathrm{~h}$ at $37^{\circ} \mathrm{C}$ in an atmosphere of $5 \% \mathrm{CO}_{2}$. After $2 \mathrm{~h}$, cell monolayers formed on the surface of the material. A $1000 \mu \mathrm{L}$ pipet tip was used to scratch a straight line along the monolayer. The debris was then removed, and the cells were washed gently using DMEM, after which additional DMEM was added to cover the cells for incubation. After $4 \mathrm{~h}$ of incubation, the DMEM was removed, and 4\% paraformaldehyde was added to facilitate the fixation process and to execute the dehydration procedure for the SEM observation. Images were captured using SEM (SU3500; Hitachi, Tokyo, Japan), and the distance traveled during the desired time frame was measured by Image $\mathrm{J}$ to determine the migration ability (Figure 2).

\subsection{Statistical Analysis}

All results in this study were presented as mean \pm standard deviation. All statistical analyses were performed by SPSS (version 20.0, IBM, Armonk, NY, USA). One-way ANOVA analyses of variance followed by post-hoc Tukey tests and independent sample $t$-test were used to analyze the data collected during this study. The statistical significance was set at a $\mathrm{p}$ value of $<0.05$. 


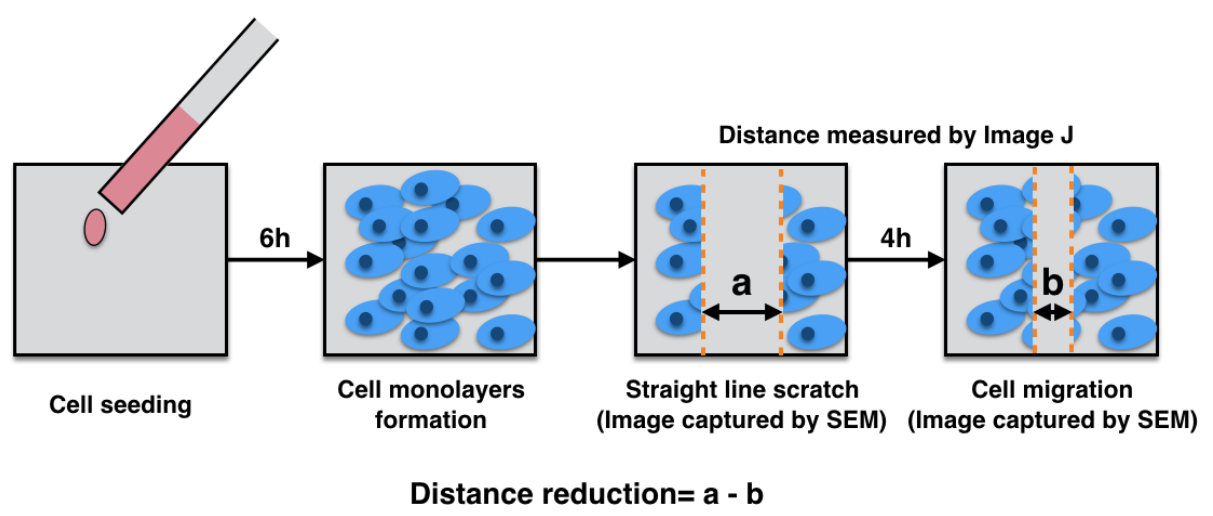

Figure 2. The migration test procedure.

\section{Results}

\subsection{Degradation Behavior}

The degradation behavior of the $\mathrm{Mg}_{66} \mathrm{Zn}_{29} \mathrm{Ca}_{5}$ bulk metallic glass samples with three different surface roughness parameters is shown in Figure 3; it includes the change in the pH value of the simulated body fluid, the weight change, and the change in the surface roughness. The samples with three different surface roughness demonstrated similar behavior with respect to $\mathrm{pH}$ change of the SBF and weight change after 4 weeks of immersion (Figure $3 a, b$ ). According to the results, there was no relationship between the change in surface roughness of the samples and the corresponding degradation behavior. The surface roughness of all samples was observed to change in the SBF during immersion. The original surface roughness values of samples, which were subjected to grinding by \#240, \#800, and \#2000 sandpapers, were 0.24, 0.22, and $0.07 \mu \mathrm{m}$, respectively. After 4 weeks of immersion, the surface roughness was found to increase to $1.01,0.74$, and $0.74 \mu \mathrm{m}$, respectively (Figure 3c).

(a)

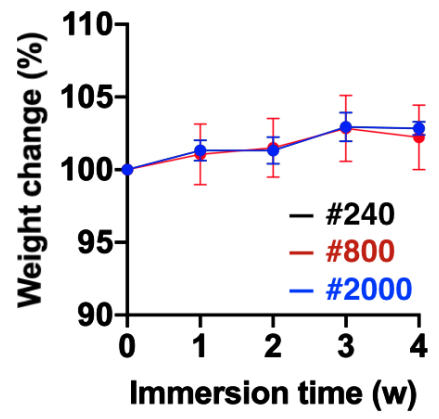

(b)

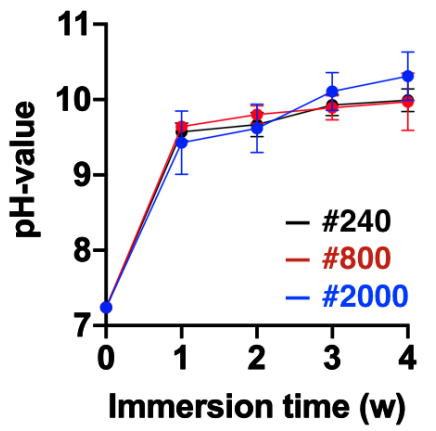

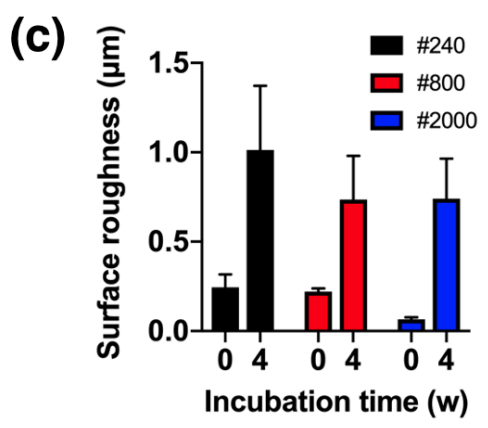

Figure 3. Behavior of $\mathrm{Mg}_{66} \mathrm{Zn}_{29} \mathrm{Ca}_{5}$ bulk metallic glass samples with three different surface roughness attributes. (a) pH change of simulated body fluid, (b) weight loss of sample, and (c) surface roughness change. 


\subsection{Microstructure Characterization}

The XRD patterns of the $\mathrm{Mg}_{66} \mathrm{Zn}_{29} \mathrm{Ca}_{5}$ bulk metallic glass samples with three different surface roughness parameters prior to and after four weeks of immersion are shown in Figure 4. Prior to immersion, all sample groups showed a typical broad diffraction peak around $30^{\circ}-50^{\circ}$ of glassy matrix with a $\mathrm{Mg}_{0.97} \mathrm{Zn}_{0.03}$ phase crystalline peak (Figure 4a). However, after degradation by the immersion test, the amorphous matrix decreased, and the crystalline peak then appeared because of the generation of corrosion residues in the samples (Figure 4 b).

(a)

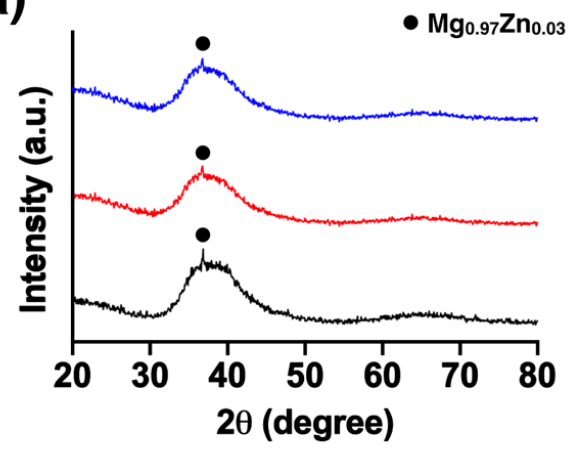

(b)

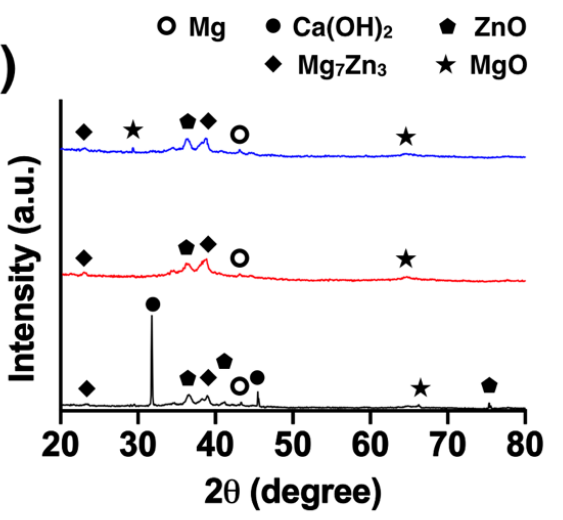

Figure 4. Pattern of $\mathrm{Mg}_{66} \mathrm{Zn}_{29} \mathrm{Ca}_{5}$ bulk metallic glass samples with three different surface roughness parameters (a) prior to the immersion test and (b) after 4 weeks of immersion.

\subsection{Observation of Surface Morphologies}

The surface morphologies of the $\mathrm{Mg}_{66} \mathrm{Zn}_{29} \mathrm{Ca}_{5}$ bulk metallic glass with three different surface roughness parameters prior to and after 4 weeks of immersion are shown in Figure 5. Prior to degradation from immersion, the surfaces were flat, and the grinding trace of the sandpaper were clearly visible. After 4 weeks of immersion, the surfaces of the samples changed, and the roughness increased for all groups.

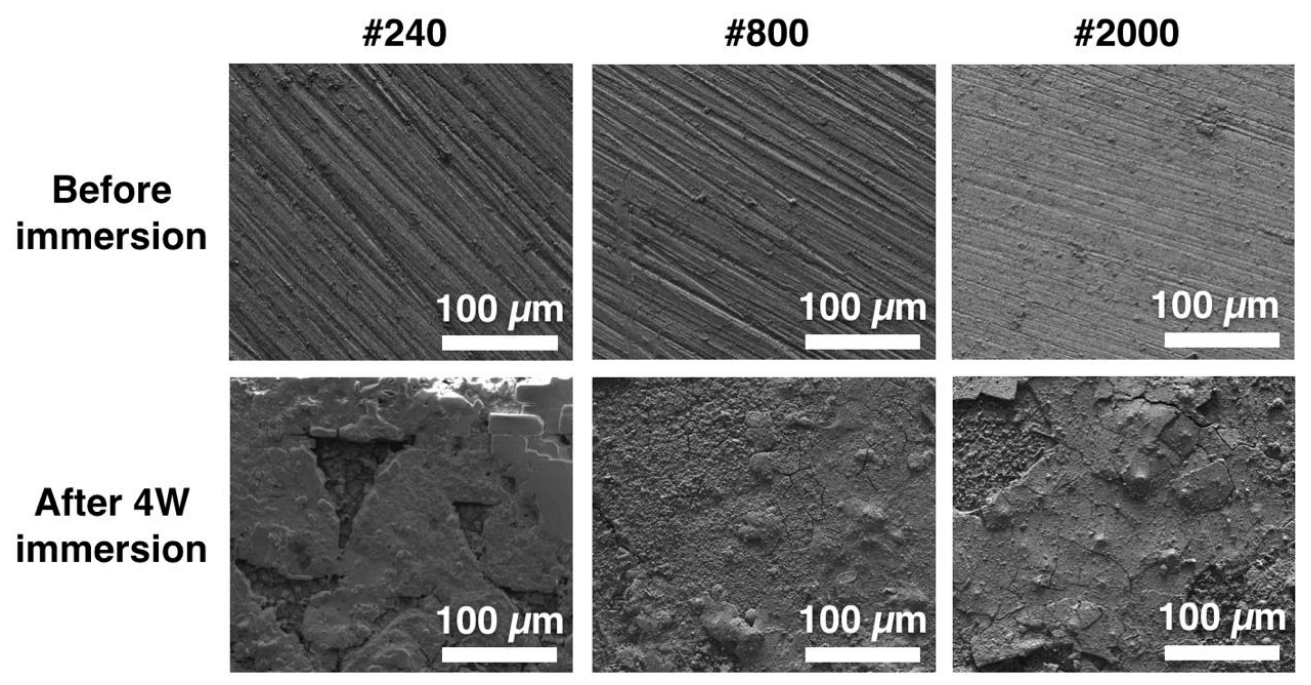

Figure 5. Morphology observations of $\mathrm{Mg}_{66} \mathrm{Zn}_{29} \mathrm{Ca}_{5}$ bulk metallic glass samples with three different surface roughness parameters before and after the four-week immersion test.

\subsection{Cell Adhesion and Spreading}

The cell adhesion morphology on the $\mathrm{Mg}_{66} \mathrm{Zn}_{29} \mathrm{Ca}_{5}$ bulk metallic glass samples with different surface roughness were captured by SEM after fixation and a dehydration process (Figure 6). The three 
different surface roughness factors were all found to provide a suitable surface for MG63 cell adhesion with a distinct spindle shape. The well-expanded cytoskeleton of the MG63 cells on the three different surfaces, the formation of the pseudopodia, and the pronounced spreading on the different surface samples demonstrated that the cells were tightly attached (indicated by arrow) (Figure 6a-c). The MG63 cells not only formed two-dimensional structures but also three-dimensional structures, with the many cell-cell interactions able to be clearly visualized (Figure 6d-f). However, different percentages of cell coverage were observed on the different surfaces. The greatest percentage of cell coverage area was observed for the samples from the group ground with the \#800-grade sandpaper (Figure 6g), at 80.96\%.

(a)

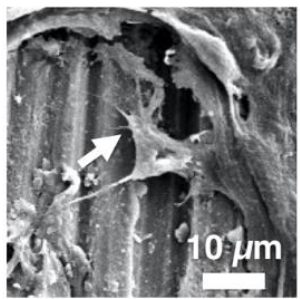

(d)

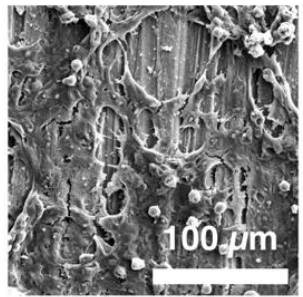

(b)

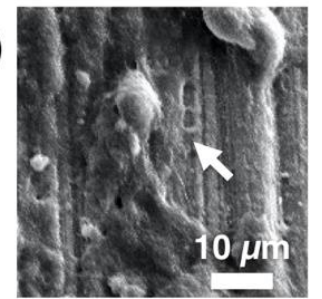

(e)

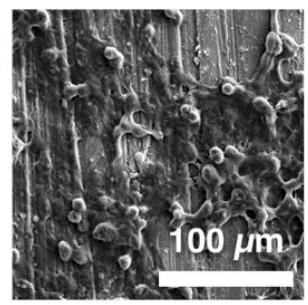

(c)

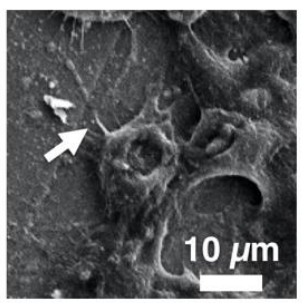

(f)

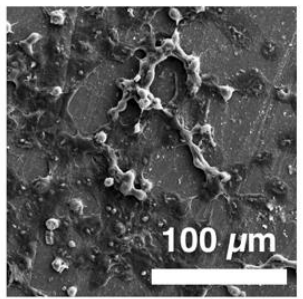

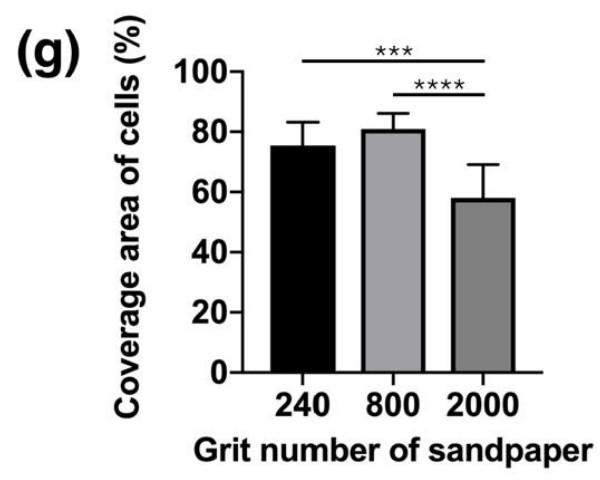

Figure 6. Cell adhesion observed on the $\mathrm{Mg}_{66} \mathrm{Zn}_{29} \mathrm{Ca}_{5}$ bulk metallic glass samples with different surface roughness. SEM images of the cells, which attached on the surfaces polished using (a,d) \#240, (b,e) \#800, and (c,f) \#2000 grades of sandpaper; (g) quantified adhesion of MG63 cells. The cytoskeleton of the MG63 cells was well-expanded, and spreading and formation of pseudopodia on the surface of the $\mathrm{Mg}_{66} \mathrm{Zn}_{29} \mathrm{Ca}_{5}$ bulk metallic glass was apparent (indicated by the arrow). $\left({ }^{*} p<0.05,{ }^{* *} p<0.01\right.$, *** $p<0.005$, and $\left.{ }^{* * * *} p<0.001\right)$.

\subsection{Cell Viability}

The cell viability of the MG63 cells (normalized against the control group) cultured on the $\mathrm{Mg}_{66} \mathrm{Zn}_{29} \mathrm{Ca}_{5}$ bulk metallic glass samples with different surface roughnesses is shown in Figure 7 . The surface of the samples polished with the \#800-grade sandpaper was observed to have the greatest cell viability when compared with the samples polished with the sandpaper grades. The cell viabilities of the $\mathrm{Mg}_{66} \mathrm{Zn}_{29} \mathrm{Ca}_{5}$ bulk metallic glass samples polished with the \#240, \#800, and \#2000 grade sandpapers were $76.9 \pm 0.2,91.4 \pm 0.3$, and $68.8 \pm 0.2$, respectively. According to ISO 10993-5 [18], the cell viability of the \#800 group is classified as first-level cytotoxicity (slight-cell survival rate higher than $80 \%$ ), and that for the \#240 and \#2000 groups is classified as second-level (mild-cell survival rate higher than $50 \%$ ). 


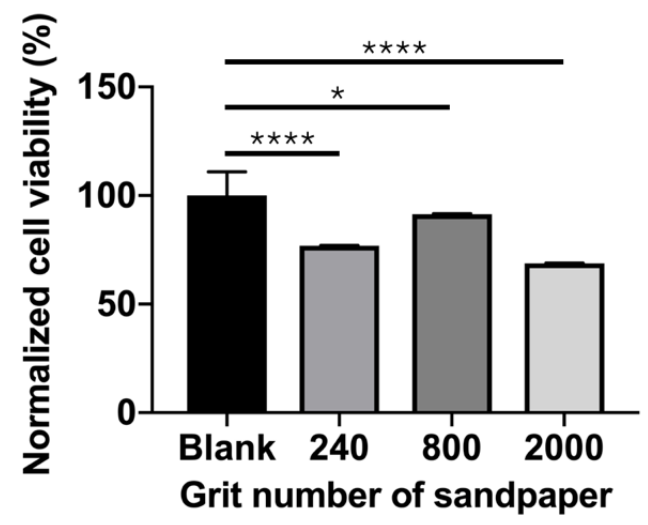

Figure 7. Viability of the MG63 cells, which were cultured on the different $\mathrm{Mg}_{66} \mathrm{Zn}_{29} \mathrm{Ca}_{5}$ bulk metallic glass surface samples for three days. ${ }^{*} p<0.05,{ }^{* *} p<0.01,{ }^{* * *} p<0.005$, and $\left.{ }^{* * *} p<0.001\right)$.

\subsection{Extracellular-matrix Calcium Deposition}

The extracellular-matrix calcification of the MG63 cells was detected using Alizarin Red S staining. The quantitative analysis of the ARS dye that solubilized with DMSO after normalization is shown in Figure 8 . The calcium deposition rates observed on the samples with different surface roughness was $97.26 \pm 2.12 \%$ for the \#240 group, $84.81 \pm 0.99 \%$ for the \#800 group, and $78.33 \pm 3.04 \%$ for the \#2000 group (Figure 8a). On the other hand, the $\mathrm{Mg}_{66} \mathrm{Zn}_{29} \mathrm{Ca}_{5}$ bulk metallic glass samples without MG63 cells have no extracellular-matrix calcification on the surface (Figure 8b).

(a)

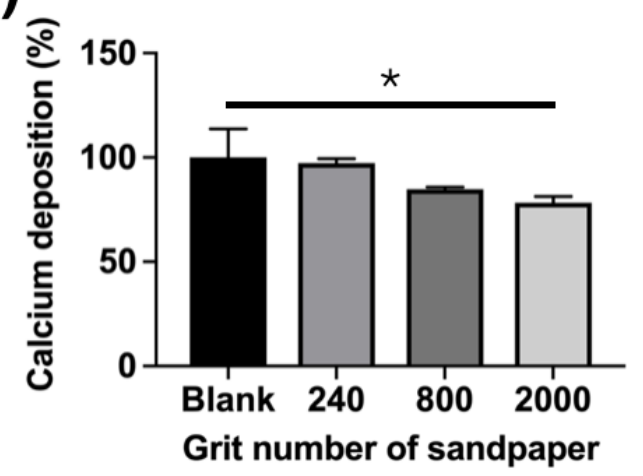

(b)

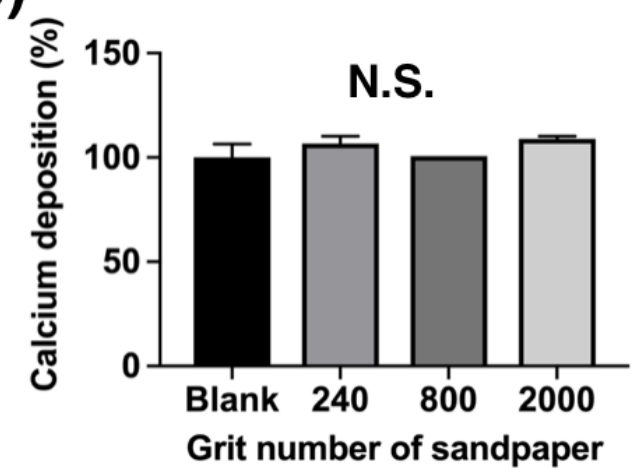

Figure 8. Quantitative results for (a) extracellular-matrix calcium and mineral deposition by MG63 cells cultured on the surface of the $\mathrm{Mg}_{66} \mathrm{Zn}_{29} \mathrm{Ca}_{5}$ bulk metallic glass samples. (b) without MG63 cells cultured on the surface of the $\mathrm{Mg}_{66} \mathrm{Zn}_{29} \mathrm{Ca}_{5}$ bulk metallic glass sample. Alizarin red $\mathrm{S}$ staining method was used in this test. ( $\mathrm{N}=5$ per group; ${ }^{*} p<0.05,{ }^{* *} p<0.01,{ }^{* * *} p<0.005$, and ${ }^{* * *} p<0.001$ ).

\subsection{Migration Capacity}

To shorten the period required for a bone to heal and to enhance the cell migration velocity for cells to attach to the area surrounding the implanted material, materials with three different surface roughness factors were tested. After gap generation, MG63 cells had $4 \mathrm{~h}$ to migrate during incubation. The gap can be seen clearly in Figure 9a as commencing after $4 \mathrm{~h}$ of incubation. The different surface roughness attributes of the samples exhibited different gap distances even though each was created using the same pipet tip size. The distance of the gap, which was created by the pipet tip, was reduced through the migration of MG63 cells. The reduced distance was measured using Image J software (results are shown in Figure 9b). It was found that the reduction in the gap distance of the \#800 group $(255 \pm 50 \mu \mathrm{m})$ and the \#2000 group $(201 \pm 19 \mu \mathrm{m})$ were significantly higher than that observed for the \#240 group $(66 \pm 13 \mu \mathrm{m})$. The high magnification of cell migration after $4 \mathrm{~h}$ of incubation is shown in Figure $9 c$. 
(a)

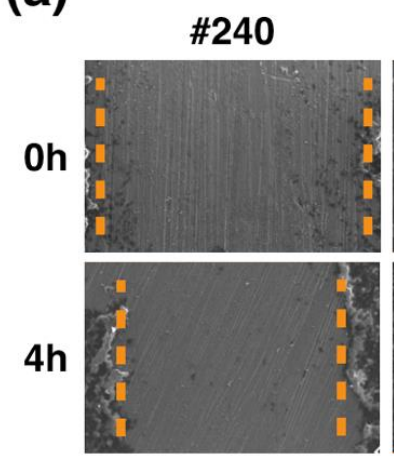

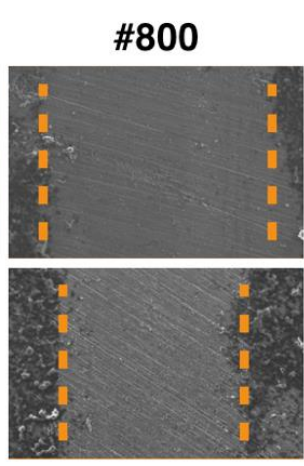

\#2000
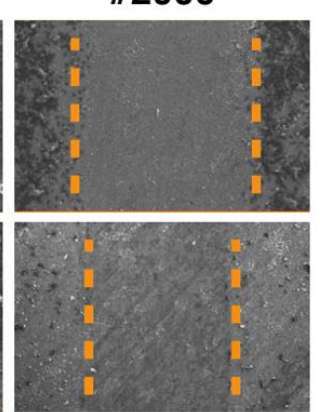

$0.5 \mathrm{~mm}$ (b)

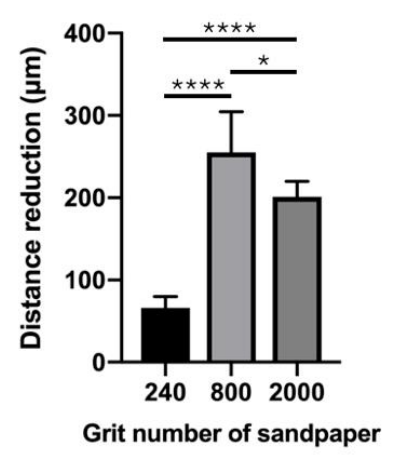

(c)

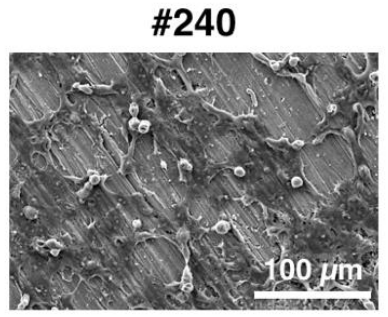

\#800

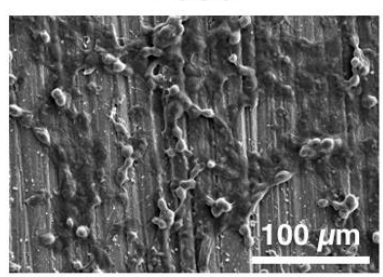

\#2000

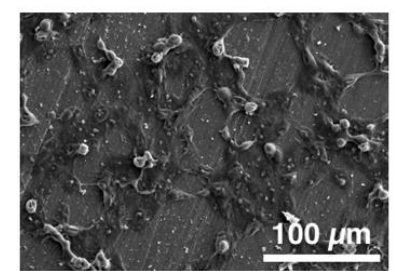

Figure 9. Capacity of MG63 cells cultured on $\mathrm{Mg}_{66} \mathrm{Zn}_{29} \mathrm{Ca}_{5}$ bulk metallic glass samples with three different surface roughness characteristics. (a) SEM image of migrated cells. (b) Distance reduction of the gap due to migration of MG63 cells. (c) High magnification image of cell migration morphology after 4 h of incubation. $\left({ }^{*} p<0.05,{ }^{* *} p<0.01,{ }^{* * *} p<0.001\right.$, and $\left.{ }^{* * * *} p<0.001\right)$.

\section{Discussion}

$\mathrm{Mg}_{66} \mathrm{Zn}_{29} \mathrm{Ca}_{5}$ bulk metallic glass is an amorphous structure material that can be considered as a single-crystal material due to its homogeneous and uniform arrangement. Thus, the $\mathrm{Mg}_{66} \mathrm{Zn}_{29} \mathrm{Ca}_{5}$ bulk metallic glass material remains as a single crystal structure after being polished by different grades of sandpaper. The retention of the crystal structures is responsible for the lack of difference in the degradation behavior observed for the $\mathrm{Mg}_{66} \mathrm{Zn}_{29} \mathrm{Ca}_{5}$ bulk metallic glass samples of varying surface roughness, as seen in Figure 3a,b. However, the surface roughness varied greatly after 4 weeks of degradation (Figure 3c). The variation in the roughness of the samples surface was not observed to influence the recorded change in weight and $\mathrm{pH}$ value, which remained stable. As such, the surface roughness change caused by degradation of the samples occurred uniformly and homogeneously. Compared with Mg crystalline alloy, AZ91 magnesium alloy, the pitting corrosion increased the progress of degradation in which the stress corrosion crack contributed to material failure [16]. Moreover, the microstructure of the metallic glass gradually crystallized as degradation time increased [13]. From our results, $\mathrm{Mg}_{66} \mathrm{Zn}_{29} \mathrm{Ca}_{5}$ bulk metallic glass was observed to exhibit decreased amorphous phase after 4 weeks of immersion. It should be noted that the surface of the samples polished with \#240 grade sandpaper was observed to have the greatest crystalline signal in the XRD pattern (Figure 4b); presumably, the corrosion products more easily formed and cohered on the rough surface. Nguyen et al. previously reported that the corrosion rate observed for rough surface samples of as-cast $\mathrm{Mg}$ was significantly higher than that for smooth samples [19]. This higher corrosion rate may lead to more corrosion products being generated on the rough surface.

The surface of implant materials is the first site in contact with the surrounding cells and tissue. In this study, for Mg-based BMG of the same composition, the surface roughness was found to be the only factor determining the biocompatibility and cell adhesion of MG63 cells to $\mathrm{Mg}_{66} \mathrm{Zn}_{29} \mathrm{Ca}_{5}$ bulk metallic glass. Recently, orthopedic implants have been used as functional coating or to increase surface roughness to enhance the resulting biocompatibility, biological fixation, and osteoconductive properties [20,21]. However, the surface of $\mathrm{Mg}$ materials changes over time because of their biodegradable properties. 
Thus, using physical methods (e.g., grinding) to treat the original metallic surface may be a direct way of improving the biological effectiveness for cells without requiring any coating. According to the results in this study, a surface roughness of around $0.22 \mu \mathrm{m}$ (\#800 group) was shown to result in the greatest cell coverage area after $24 \mathrm{~h}$ of incubation (Figure 6). After 3 days of incubation, the \#800 group also showed the highest cell viability (Figure 7). A surface roughness of $0.22 \mu \mathrm{m}$ therefore seems to provide a good platform for initial cell adhesion and survival. The entrapment of fibrin protein has been encouraged by the rough surface, increased the adhesion of osteogenic cells and enhanced the mechanical stability of implants in human bone, our work [22-28]. To facilitate osteointegration, the dense bone tissue has to entirely cover the surface of the material. The materials should not only have good cell proliferation but also be effective in recruiting cells from the surrounding tissue to achieve this ideal situation. In the results obtained from our study, the samples polished using the \#800-grade sandpaper demonstrated the best migration ability for the MG63 cells. However, the most effective calcium deposition was observed for the samples polished with the \#240 grade sandpaper; unfortunately, \#240 group showed the worst cell migration ability.

When considering the surface roughness of material designed for orthopedic implants, the surface should be varied according to the different stages of osteointegration. For example, materials with a surface roughness of $\# 800$ are best for initial cell adhesion, cell migration, and cell proliferation; an increased surface roughness will support improvements in the subsequent calcium deposition that is required for bone cells. The surface roughness variation of biodegradable magnesium material during degradation may have a strong advantage over other metal materials, which cannot be degraded when implanted in the human body.

\section{Conclusions}

In this study, $\mathrm{Mg}_{66} \mathrm{Zn}_{29} \mathrm{Ca}_{5}$ bulk metallic glass samples treated to produce samples with three surface roughness parameters were investigated using material properties test and in vitro study. We found that different surface roughness factors can enhance different functions for MG63 cells. However, there was no significant difference between the surface roughness of the three samples in terms of degradation behavior. For orthopedic implant applications, harnessing different surface roughness produced by degrading materials in order to regulate different functions of cells should be considered. The variation of the surface roughness of implant material can be achieved via natural or engineering processes. For the design of surface treatment, the surface roughness which polishes with \#800-grade sandpaper would be recommended to provide the surface for cell attachment. The much rougher surface would be generated naturally during degradation to provide the surface for cells to enhances the effects of calcium deposition.

Author Contributions: P.-C.W. collected the research literature; P.-C.W., S.-M.S., P.-H.T., Y.-Y.N. and J.S.-C.J. designed and performed the experiments; P.-C.W. organized the layout of manuscript; J.S.-C.J., C.-K.C., and C.-H.C. discussed and provided suggestions for the content; P.-C.W. wrote the paper. All authors reviewed the paper and made additional comments on this manuscript. All authors have read and agreed to the published version of the manuscript.

Funding: This research was funded by the Ministry of Science and Technology of Taiwan, grant number MOST 108-2218-E-038-001 and Taipei Medical University within the framework of the Higher Education Sprout Project by the Ministry of Education in Taiwan, grant number DP2-108-21121-01-O-02.

Acknowledgments: The authors would also like to acknowledge the technical support provided by the TMU Core Facility. We would like to thank Uni-edit (www.uni-edit.net) for editing and proofreading this manuscript.

Conflicts of Interest: The authors declare no conflicts of interest. 


\section{References}

1. Anselme, K.B.M. On the relation between surface roughness of metallic substrates and adhesion of human primary bone cells. Scanning 2014, 36, 11-20. [CrossRef] [PubMed]

2. Zhang, Y.; Chen, S.E.; Shao, J.; Van den Beucken, J. Combinatorial Surface Roughness Effects on Osteoclastogenesis and Osteogenesis. ACS Appl. Mater. Interfaces 2018, 10, 36652-36663. [CrossRef] [PubMed]

3. Wu, Y.; Zitelli, J.P.; TenHuisen, K.S.; Yu, X.; Libera, M.R. Differential response of Staphylococci and osteoblasts to varying titanium surface roughness. Biomaterials 2011, 32, 951-960. [CrossRef] [PubMed]

4. Damiati, L.; Eales, M.G.; Nobbs, A.H.; Su, B.; Tsimbouri, P.M.; Salmeron-Sanchez, M.; Dalby, M.J. Impact of surface topography and coating on osteogenesis and bacterial attachment on titanium implants. J. Tissue Eng. 2018, 9. [CrossRef] [PubMed]

5. Ma, T.G.X.; Zhang, Y.; Lin, Y. Interface Oral Health Science; Suzuki, O., Sasaki, K., Takahashi, N., Eds.; Springer: New York, NY, USA, 2017.

6. Lu, S.L.; Su, P.Y.; Li, C.L.; Wang, L.F.; Lu, H.K. Regulation of Pre-Osteoblast Osteogenic Transcription Factors by Different Titanium Surface Topography. J. Dent. Health Oral Disord. Ther. 2017, 8. [CrossRef]

7. Schneider, G.B.; Perinpanayagam, H.; Clegg, M.; Zaharias, R.; Seabold, D.; Keller, J.; Stanford, C. Implant Surface Roughness Affects Osteoblast Gene Expression. J. Dent. Res. 2003, 82, 372-376. [CrossRef]

8. Puckett, S.P.R.; Webster, T.J. Nano rough micron patterned titanium for directing osteoblast morphology and adhesion. Int. J. Nanomed. 2008, 3, 229-241.

9. Kubies, D.; Himmlová, L.; Riedel, T.; Chánová, E.; Balík, K.; Douděrová, M.; Bártová, J.; Pešáková, V. The interaction of osteoblasts with bone-implant materials: 1 . The effect of physicochemical surface properties of implant materials. Physiol. Res. 2011, 60, 95-111. [CrossRef]

10. Marinucci, L.; Balloni, S.; Becchetti, E.; Belcastro, S.; Guerra, M.; Calvitti, M.; Lull, C.; Calvi, E.M.; Locci, P. Effect of titanium surface roughness on human osteoblast proliferation and gene expression in vitro. Int. J. Oral Maxillofac. Implants 2006, 21, 719-725.

11. Yamashita, D.; Machigashira, M.; Miyamoto, M.; Takeuchi, H.; Noguchi, K.; Izumi, Y.; Ban, S. Effect of surface roughness on initial responses of osteoblast-like cells on two types of zirconia. Dent. Mater. J. 2009, 28, 461-470. [CrossRef]

12. King, A.; Johnson, G.; Engelberg, D.; Ludwig, W.; Marrow, J. Observations of Intergranular Stress Corrosion Cracking in a Grain-Mapped Polycrystal. Science 2008, 321, 382-385. [CrossRef] [PubMed]

13. Wong, P.C.; Tsai, P.H.; Li, T.H.; Cheng, C.K.; Jang JS, C.; Huang, J.C. Degradation behavior and mechanical strength of $\mathrm{Mg}-\mathrm{Zn}-\mathrm{Ca}$ bulk metallic glass composites with Ti particles as biodegradable materials. J. Alloy. Compd. 2017, 699, 914-920. [CrossRef]

14. Melchers, R.E.J.R. Surface “Roughness" Effect on Marine Immersion Corrosion of Mild Steel. Corrosion 2004, 60, 697-703. [CrossRef]

15. Alvarez, R.B.; Martin, H.J.; Horstemeyer, M.F.; Chandler, M.Q.; Williams, N.; Wang, P.T.; Ruiz, A. Corrosion relationships as a function of time and surface roughness on a structural AE44 magnesium alloy. Corros. Sci. 2010, 52, 1635-1648. [CrossRef]

16. Walter, R.; Kannan, M.B.; He, Y.; Sandham, A. Effect of surface roughness on the in vitro degradation behaviour of a biodegradable magnesium-based alloy. Appl. Surf. Sci. 2013, 279, 343-348. [CrossRef]

17. American Society for Testing and Materials. ASTM-G31e72: Standard practice for laboratory immersion corrosion testing of metals. In Annual Book of ASTM Standards; ASTM: Philadelphia, PA, USA, 2004.

18. International Orgenization for Standardization. ISO-10993-5: Biological Evaluation of Medical Devices Part 5: Test for Cytotoxicity. In Vitro Methods; ANSI/AAMI: Arlington, VA, USA, 1999.

19. Nguyen, T.L.; Blanquet, A.; Staiger, M.P.; Dias, G.J.; Woodfield, T.B. On the role of surface roughness in the corrosion of pure magnesium in vitro. J. Biomed. Mater. Res. B Appl. Biomater. 2012, 100, 1310-1318. [CrossRef]

20. Kurashina, K.K.H.; Wu, Q.; Ohtsuka, A.; Kobayashi, H. Ectopic osteogenesis with biphasic ceramics of hydroxyapatite and tricalcium phosphate in rabbits. Biomaterials 2002, 23, 407-412. [CrossRef]

21. Svehla, M.; Morberg, P.; Bruce, W.; Zicat, B.; Walsh, W.R. The effect of substrate roughness and hydroxyapatite coating thickness on implant shear strength. J. Arthroplast. 2002, 17, 304-311. [CrossRef]

22. Liu, X.; Poon Ray, W.Y.; Kwok Sunny, C.H.; Chu Paul, K.; Chuanxian, D. Plasma surface modification of titanium for hard tissue replacements. Sur. Coat. Tech. 2004, 186, 227-233. [CrossRef] 
23. Wei, M.; Kim, H.M.; Kokubo, T.; Evans, J.H. Optimising the bioactivity of alkaline-treated titanium alloy. Mat. Sci. Eng. C 2002, 20, 125-134. [CrossRef]

24. Lamolle, S.F.; Monjo, M.; Rubert, M.; Haugen, H.J.; Lyngstadaas, S.P.; Ellingsen, J.E. The effect of hydrofluoric acid treatment of titanium surface on nanostructural and chemical changes and the growth of MC3T3-E1 cells. Biomaterials 2009, 30, 736-742. [CrossRef] [PubMed]

25. Yousefpour, M.; Afshar, A.; Chen, J.; Xingdong, Z. Bioactive layer formation on alkaline-acid treated titanium in simulated body fluid. Mat. Des. 2007, 28, 2154-2159. [CrossRef]

26. Geetha, M.; Singh, A.K.; Asokamani, R.; Gogia, A.K. Ti based biomaterials, the ultimate choice for orthopaedic implants: A review. Prog. Mat. Sci. 2009, 54, 397-425. [CrossRef]

27. Elias Carlos, N.; Oshida, Y.; Lima Jose Henrique, C.; Muller Carlos, A. Relationship between surface properties (roughness, wettability and morphology) of titanium and dental implant removal torque. J. Mech. Behav. Biomed. Mater. 2008, 1, 234-242. [CrossRef]

28. Ellingsen, J.E.; Johansson, C.B.; Wennerberg, A.; Holman, A. Improved retention and bone-to-implant contact with fluoride-modified titanium implants. Int. J. Oral Maxillo. Imp. 2004, 19, 659-666.

(C) 2020 by the authors. Licensee MDPI, Basel, Switzerland. This article is an open access article distributed under the terms and conditions of the Creative Commons Attribution (CC BY) license (http://creativecommons.org/licenses/by/4.0/). 